\title{
W imię zmarłych: humanistyka forensycznej wrażliwości i publicznej prawdomówności
}

Roma Sendyka

TEKSTY DRUGIE 2017, NR 1, S. 81-90

DOI: $10.18318 /$ td.2017.1.6

\section{W imię zmarłych: praktyki forensyczne}

Tłumaczenie słowa "forensyczny" stało się ostatnio łatwiejsze dzięki kulturze masowej: seriale łączące tradycje kryminału i nową poetykę laboratoryjną wypełniły naszą wyobraźnię odpowiednimi odnośnikami. Kryminalistyka, dochodzenie sądowe - trudno dostrzec, jakie ewentualne korzyści miałaby odnieść współczesna humanistyka, spoglądając w stronę tych szczególnie wyspecjalizowanych i zaawansowanych badań. A jednak coraz częściej słychać o nadchodzącym zwrocie forensycznym: coraz dynamiczniej rozwijają się działania ruchu łączącego artystów, naukowców i humanistów. Potraktuję tu tę nową strategię analizy jako wezwanie do przemyślenia kwestii rudymentarnych: co jest stawką - będę pytała - tą najwyższą, ostateczną stawką, o którą bylibyśmy skłonni walczyć, robiąc to, co robimy?

Chciałabym rozpocząć od dwóch przykładów działań wykorzystujących metody forensyczne. Pierwszą będzie projekt artystyczny Mateusza Kuli, artysty pracującego w Krakowie i Wiedniu [jego prace w 2016 roku można było zobaczyć w nowej galerii Elementarz dla
Roma Sendyka dr hab., pracuje w Katedrze Antropologii Literatury i Badań Kulturowych WP UJ, prowadzi Centrum Badań nad Kulturami Pamięci. Zajmuje się teoriami badań literackich i kulturowych, w tym zwłaszcza badaniami nad kulturą wizualną i kulturami pamięci. Autorka książek Nowoczesny esej. Studium historycznej świadomości gatunku (2006), Od kultury ja do kultury siebie (2015), współredaktorka serii "Nowa Humanistyka". 
mieszkańców miast przy ul. Asnyka w Krakowie oraz na wystawie Tekst ijego wykonanie w Bunkrze Sztuki]. Mam na myśli projekt z roku 2015, zatytułowany Forensics of Family Photographs / Looking for life on the photographs of dead people [Forensyka fotografii rodzinnych. Szukanie życia na fotografiach zmarłych]. Artysta zatrudnił biegłego, czyli laboranta kryminalistycznego, do zbadania i identyfikacji organicznych i nieorganicznych mikrośladów na powierzchni fotografii wykonanej w Ropczycach cztery dni przed rozpoczęciem II wojny światowej. Znalezione w wyniku tej współpracy zadrapania, ślady tekstyliów i pleśni nie tylko budują zarys możliwych losów odbitki, ale także animują nieżywy obiekt: indeksalne ślady życia (noszenia, składowania, dotykania) są wciąż obecne, choć nie ma już sprawców tych działań.

Drugi przykład jest efektem prac międzynarodowego zespołu archeologów ${ }^{1}$ na terenie byłego obozu koncentracyjnego w Sobiborze. Wykopaliska prowadzone między rampą a tzw. Himmelfahrtstrasse ujawniły wiele artefaktów, a także coś, co doprowadziło do radykalnych zmian projektu upamiętnienia i przesunięcia planowanych dla tego terenu zabudowań. $\mathrm{Na}$ terenie obozu II oraz na drodze prowadzącej do komór gazowych znaleziono połacie zbitej ziemi: efekt przemieszczania się po niej wielu osób, rezultat długotrwałego oczekiwania stłoczonych więźniów. To tak zwane „udeptanisko" - indeksalny ślad obecności ofiar obozu: relikt który skutecznie uwspółcześnia przeszłą obecność więźniów. Trwający wciąż efekt dotyku wydaje się zbliżać nas do przeszłego życia bardziej, niż dzieje się w przypadku medialnie zapośredniczonych opowieści o nim.

W obu przykładach, zakorzenionych w odmiennych praktykach, spokrewnionych jednak podobnym gestem badań typowych dla postępowań sądowych, nie chodzi o ekscytację, fetyszyzację dowodu (tzw. CSI Effect²)

1 Badaniami kierował Wojciech Mazurek (Sub Terra) współpracujący z archeologiem z Izraela Yoramem Haimim (Instytut Yad Vashem). Nadto w badaniach w charakterze konsultantów naukowych uczestniczyli: prof. Barbara Kutyłowska i prof. Andrzej Kola.

2 Termin „CSI Effect” jest używany w interpretacjach kultury prawniczej i zjawisk medialnych. Dotyczy on możliwego wpływu, jaki mają seriale telewizyjne pokazujące zaawansowane metody śledcze na zachowania ławników i rad przysięgłych (i szerzej - społeczeństwa obserwującego prace służb specjalnych). Telewizyjna fikcja buduje przekonanie o możliwości dostarczenia niezbitego dowodu zbrodni, potwierdzonego autorytetem nauk ścisłych. Statystyki wykazują, że przysięgli podnieśli w ostatniej dekadzie swe oczekiwania w sprawie niezbitego dowodu i częściej niż uprzednio zasądzają uniewinnienie. Efekt opisywany jest od połowy lat 2000, dotyczy serialu CSI: Crime Scene Investigation i kolejnych spokrewnionych z nim seriali z gatunku police procedural drama, pokazywanego od października 2000 roku. Por. np. D.R Baskin, I.B. Sommers Crime-Show-Viewing Habits and Public Attitudes Toward 
czy złudzenie dotarcia do poziomu fizycznie definiującej się faktyczności. Stawką jest raczej publiczne domaganie się sprawiedliwości, ujawnianie zbrodni, przeciwstawianie się kłamstwu, występowanie przeciwko wojnie, szerzej: upomnienie się o nieżywych. Oba projekty były prowadzone wimięzmartych.

\section{W imię jeszcze żywych: prawo do przeżycia}

Przywoływanie śmiertelnych ofiar, jak pisała Judith Butler w Ramach wojny, wydobywa „na światło dzienne nie tylko skończony charakter życia”, ale i kruchość tego istnienia, które jeszcze trwa ${ }^{3}$. Gdy dziś nieomal codziennie dowiadujemy się o ofiarach śmiertelnych, gdy ludzki koniec raportowany jest jako zdarzenie masowe, gdy powtarzalność tej informacji czyni ją redundantną, czy możliwy jest niezdewaluowany powrót do pierwotnego gestu humanistycznego, jakim byłoby domaganie się uznania szczególnej wartości pojedynczego ludzkiego życia? „Humanizm” chciałabym tu rozumieć nie jako "prąd kulturalno-literacki” czy „system pedagogiczny”, ale poza-filologicznie, jako filozoficzny autoreferencyjny gest zgłębiania ludzkiego bycia, „kondycji ludzkiej", kulminujący u końca XVIII wieku w akcie sformułowania uniwersalnych praw człowieka ${ }^{5}$, których punktem wyjścia było podstawowe prawo egzystencjí.

Zwracanie uwagi na ludzką kruchość jest skuteczne, twierdziła Butler, o ile zostanie ujęte w takie ramy, które wytworzą afekt ${ }^{7}$ mający polityczny

Forensic Evidence: The "CSI Effect" Revisited, "Justice System Journal" 2010 No. 1; S.A. Cole, R. Dioso-Villa Investigating the 'CSI Effect' Effect: Media and Litigation Crisis in Criminal Law, "Stanford Law Review", 2009 No. 6; K. Podlas The 'CSI Effect' and Other Forensic Fictions, "Loyola of Los Angeles Entertainment Law Review" 2007 No. 2; N.J. Schweitzer, M.J. Saks The CSI Effect: Popular Fiction About Forensic Science Affects Public Expectations About Real Forensic Science, ") Jurimetrics” 2007 No. 47.

3 J. Butler Ramy wojny. Kiedy życie godne jest opłakiwania, przeł. A. Czarnacka, Instytut Wydawniczy Książka i Prasa, Warszawa 2011, s. 57.

4 A. Borowski Renesans, WSiP, Warszawa 1992, s. 72.

5 Mam na myśli tekst, który jest często wskazywany jako źródłowy w tym kontekście, mianowicie T. Paine Rights of Man (1792).

6 T. Paine użył frazy right of existence w powyżej wspomnianej pracy, por. http://www.let.rug.nl/ usa/documents/1786-1800/thomas-paine-the-rights-of-man/text.php (20.08.2016).

7 J. Butler Ramy wojny..., s. 56. 
efekt. Oba wspomniane przed chwilą forensyczne działania miały taki skutek: uruchomiły przynajmniej (jeśli nie więcej niż) emocję poczucia bliskości. Wskazały na „kruchość życia wytraconego na wojnie”, ale też więcej: emocja ta natychmiast przekształca się w „etyczny i polityczny sprzeciw wobec strat wywoływanych przez konflikty wojenne"8. Owo „więcej” ma dla mnie szczególne znaczenie. Innymi słowy, wspomniane projekty forensyczne były prowadzone nie tylko w imię zmartych, ale także, może nawet przede wszystkim, wimięjeszcze żywych.

Współczesne zmiany cywilizacyjne nieomal natychmiast konfrontują humanistów z zagrożeniem prawa do egzystencji, świadomość natury praktyk globalizacji nie pozwala na poważne podtrzymywanie złudzenia braku współwiny czy współodpowiedzialności wobec geograficznie oddalonych wydarzeń. To nakłada na humanistykę bardziej niż kiedykolwiek

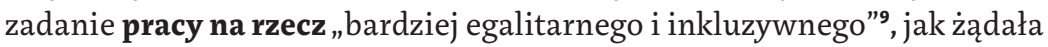
Butler, dostrzeżenia i uznania (podwójne znaczenie słowa regard) źródłowego prawa do życia, ukierunkowując tym samym studia humanistyczne na ich ideowe źródła. W tej sytuacji pilnym zadaniem humanistyki byłaby nie tyle ochrona i opracowywanie cywilizacyjnego dorobku ludzkości (model „filologiczny”) ${ }^{\mathbf{1 0}}$, ile aktywne działanie na rzecz - jak to celnie sformułowała Donna Haraway - przetrwania: „Potrzebujemy siły nowoczesnych teorii krytycznych na temat wytwarzania znaczeń i ciał, nie po to, by im zaprzeczyć, ale po to, by zbudować znaczenia i ciała, które mają szanse przeżyć"11 - pisała w Wiedzy usytuowanej. Jeśli przeżycie jest uzależnione od czynienia życia znośniejszym i bardziej bezpiecznym dla coraz większej liczby ludzi, to rację może mieć Michael Sandel, który w tłumaczonej na język polski książce-biblii ruchu Occupy Sprawiedliwość. Jak postępować

8 Tamże.

9 Tamże.

10 Mam na myśli rozróżnienie między koncepcjami humaniora i humanitas: por. A. Borowski Reneseans, s. 57: humanitas to skomplikowany i niejednoznaczny termin oznaczający "człowieczeństwo”; to Petrarkiańska „miłość bliźniego ceterorum hominum caritas jako motor i cel studiów humanistycznych" - s. 79; Natomiast już w początkach XIX wieku humanizm był rozumiany jako humaniora, czyli „ogólne wykształcenie klasyczne”; jako system pedagogiczny - s. 71-72.

11 D. Haraway Wiedza usytuowana: problem z naukq w feminizmie a przywilej przyjęcia częściowej, niepełnej perspektywy, przeł. A. Derra, w: Studia nad naukq̨ i technologiq. Wybór tekstów, red. E. Bińczyk, A. Derra, Wydawnictwo Naukowe UMK, Toruń 2014, s. 109. 
stusznie? z 2010 roku $^{12}$ zalecał szczególną troskę o jeden z trzech filarów potrzebnych do wspierania dobrego (sprawiedliwego) życia: poza wolnością gospodarczą potrzebną do osiągania dobrobytu, wolnością jednostki gwarantowaną ustawodawstwem i ustrojem politycznym równie ważna jest sfera tzw. cnót: chodzi o wartości i idee, których nieustanna aktualizacja i rewitalizacja są potrzebne, by powszechnie utrzymać priorytetową pozycję pojęć wolności i praw człowieka, gwarantujących przeżycie i dalej: sprawiedliwe (dobre) życie.

Humanistykę w związku z powyższym chciałabym rozumieć jako dziedzinę, w której dokonuje się owa nieustanna rekonstrukcja idei i wartości, koniecznych jako podbudowa do tworzenia utylitarnych instytucji (ekonomicznych, politycznych) organizacji społecznej wspierających prawo do przeżycia i sprawiedliwego życia. W ten sposób uzasadniałabym jej fundamentalne znaczenie dla samej możliwości wystąpienia i podtrzymania zjawisk demokracji i wolnego rynku (tego samego wolnego rynku, który wymusza obecnie ograniczenie jej funkcjonowania). Innymi słowy, by podtrzymać wiarę w wartość demokracji i wolności (w tym wolnego rynku), trzeba nieustannie przypominać, dlaczego wolność i równość są ważne. Jak jednak zbudować owe nowe praktyki, o które apelowała Haraway a które czynnie wzmocniłyby fundament dobrego, bezpiecznego życia? A dalej: jak upublicznić ich istnienie i oddziaływanie, tak by znieść wątpliwości co do ich społecznej niezbywalności?

Aktywność i działanie, do którego wzywają wspominani powyżej teoretycy, sugerowałyby, że oczekiwane i potrzebne "nowoczesne teorie krytyczne na temat wytwarzania znaczeń i ciał", które chętnie utożsamiłabym z nową humanistyką, muszą odejść od modelu, który nazwałabym „humanistyką kustosza": opiekuna, stróża zarządzającego majątkiem, który wprawdzie działa, przenosząc obiekty, naprawiając, wyjaśniając ich znaczenie, ale swoją aktywność ogranicza do terenu magazynu. Nowa humanistyka powinna być raczej „humanistyką kuratora” (nie bez przyczyny postać ta staje się paradygmatyczna we współczesnych praktykach kulturowych). Kurator - użyję tu sądowego znaczenia tego terminu - podejmuje się zadań interweniujących, wychowawczo-resocjalizacyjnych, diagnostycznych, prewencyjnych i kontrolnych, wykraczając poza granice swojej instytucji. Opuszcza więc to, co określa się metaforycznie terminem „echo chambers” (kabiny pogłosowej):

12 M. Sandel Sprawiedliwość. Jak postępować słusznie, przeł. O. Siara, Kurhaus, Warszawa 2013, S. 30-31. 
zamknięty teren, w którym idee krążą, wzajemnie się wzmacniając, namnażając, bez żadnych skutków zewnętrznych. Wychodzi na forum.

\section{Humanistyka publiczna, partycypacyjna, relacyjna, forensyczna}

Wyprowadzenie działań humanistów z pojemnego magazynu na forum będę rozumieć jako akt bardziej skomplikowany niż to, co określiliśmy mianem upublicznienia humanistyki ${ }^{13}$. Public humanities, czyli zróżnicowane procesy prezentowania wyników badań akademii wśród szerszej publiczności, wbrew zapewnieniom o wspólnotowym charakterze - jak krytycznie oceniał to zjawisko John Frow ${ }^{14}$ w 2005 roku, w setnym numerze „Modern Language Association" - reprodukowały zamknięcie, dopuszczały bowiem do spotkania z klasą "pracowników wiedzy” (knowledge class) tylko tych, którzy dysponowali odpowiednim przygotowaniem (credentials), działając zasadniczo na rzecz legitymizacji wydzielenia „klasy wiedzących”, nie zaś na rzecz zniesienia podziałów.

Innych modeli inkluzywnych dostarczyły, jak pamiętamy, praktyki artystyczne. Idea partycypacji obiecywała „bardziej pozytywny, niehierarchiczny model społeczny"15. Cedując część autorytarnej kontroli na kreację wspólnotową artysta rezygnował $\mathrm{z}$ indywidualnego aktu twórczego, otrzymując w zamian wyemancypowanego partnera, będącego zarazem medium jego działań. Natomiast sztuka relacyjna, wedle założeń twórcy teorii estetyki relacyjnej Nicolasa Bourriaud, miała być działaniem, w którym artysta „wytwarzał formy, które wpisując się w otwartą czasoprzestrzeń, aktywowały dialog z widzem i zachęcały go do działania w przestrzeni publicznej. Oglądający wystawę dopełniał dzieło sztuki. Nie 'uczestniczył' (pojęcie to jest zasadniczo niewłaściwe), ale ewoluował on wewnątrz struktury dzieła sztuki" - zasadą organizującą byłaby tu 'negocjacja"'16.

Brown University Public Humanities Center - jeśli można aktywność tej jednostki potraktować jako paradygmatyczny przykład takich działań - zapewniał, że „z pomocą sztuki, kultury i historii łączy społeczności w sensowny, przystępny i zajmujący sposób". Por. https://twitter. com/publichumans (20.08.2016).

J. Frow The Public Humanities, „Modern Language Review” 2005 no. 100.

C. Bishop Introduction//Viewers as Producers, w: tejże Participation, Whitechapel/Cambridge, MIT Press, London 2006, S. 12. Nietrwałe zespolenia. Szlakiem teoretycznym od relacyjnego do "wędrującego", https://www. mocak.pl/estetyka-relacyjna (20.08.2016). 
Obie strategie skrytykowała Claire Bishop. W Sztucznych piekłach. Sztuce partycypacyjnej i polityce widowni ${ }^{17}$ dowodziła, że deklaracje tworzenia powiązań między produkowaną przez publiczność treścią i demokracją zbyt często kończyły się pustym i przewidywalnym gestem, świadczącym o niedostatku zarówno tego, co artystyczne, jak i tego, co polityczne. Akt uczestnictwa okazywał się zorganizowany wokół pozbawionego istotnej idei, pustego środka, relacyjność - uwspółcześnioną praktyką salonu. Relacyjność i partycypacja w efekcie nie sprawdziły się jako strategie budowania porozumienia wokół sfery podstawowych idei w ściśle humanistycznym celu „czynienia życia znośniejszym i bardziej bezpiecznym dla coraz większej liczby ludzi".

Na tym tle praktyka Grupy Forensis, zrzeszającej filozofów, architektów, artystów, działającej na Uniwersytecie Goldsmiths w Londynie warta jest głębszego rozważenia. Grupa ta proponuje działania spokrewnione z wyżej wspomnianymi, a jednak odmiennie formatowane. Koalicja łącząca architektów, projektantów, prawników, filmowców, badaczy z dziedziny zaawansowanych technologii, nauk ścisłych i humanistyki zajmuje się analizą przestrzenną i wizualną. Na podstawie dostarczonych zdjęć i filmów zniszczonych obiektów rekonstruuje szczegóły wojennej przemocy, wyjaśniając tym samym istotne w postępowaniu sądowym elementy konfliktu. Pracuje na zlecenie ONZ, instytucji pozarządowych czy organizacji praw człowieka. Podejmuje też historyczne i teoretyczne badania dowodów, metod kryminalistycznych i reprezentacji wykorzystywanych w imię „publicznej prawdomówności" (public truth) na rzecz praw ludzi oraz - co ważne - nie-ludzi (analizy przestępstw środowiskowych).

Zespół ma na koncie np. rekonstrukcję siły ataku rakietowego w Strefie Gazy, analizę wybuchów i ustalanie liczby ofiar w budynku w Afganistanie, badanie poziomu radioaktywności taśmy zawierającej materiał filmowy wykonany nad Czarnobylem w 1986 roku i akcję publiczną przejęcia pomnika ArcelorMittlal Orbit w londyńskim miasteczku olimpijskim na rzecz ofiar z Omarska: kopalni, z której koncern pobiera rudy żelaza, a w której podczas wojny w Jugosławii Serbowie torturowali Bośniaków i Chorwatów. Grupa współpracuje z archeologami (Caroline Sturdy Colls, Robert Jan van Pelt), osteobiografami (Clyde Snow), antropologami, teoretykami mediów (Thomas Keenan). Swoje ustalenia publikuje na stronie internetowej ${ }^{18}$ oraz

\footnotetext{
17 C. Bishop Sztuczne piekła. Sztuka partycypacyjna i polityka widowni, przeł. J. Staniszewski, Fundacja Bęc Zmiana, Warszawa 2015.

18 Por. http://www.forensic-architecture.org/ (20.08.2016).
} 
podczas wystaw prezentowanych w galeriach, muzeach, instytucjach (np. w krakowskiej Pauzie, PROA w Buenos Aires i berlińskim Haus der Kulturen der Welt. Obecnie prezentuje się na Biennale Architektury w Wenecji).

Oczywiście w tym miejscu musi pojawić się pytanie: co mogłaby humanistyka (polonistyka w szczególności) zaczerpnąć z działań tak interdyscyplinarnych i stechnicyzowanych, wymagających angażowania zaawansowanych technologii i aparatury? Jeśli wydaje się, że nic, to lider ruchu, Eyal Weizman podaje inną odpowiedź: jeśli zgodzić się, że era ludzkich świadków tego, co przeciw-ludzkie (chodzi oczywiście o odchodzenie ostatnich Ocalonych z Zagłady) powoli za nami, a świadkowie materialni (których znaczenie niepomiernie w tej sytuacji wzrasta) są niemi, to kluczową osobą w tej konstelacji staje się tłumacz, twórca prozopopei, ktoś, kto przełoży materialność obiektu na narrację, kto jest szczególnie uprawniony i przygotowany do konstytuowania forum: ten, kto podejmie pierwotną funkcję retora. Innymi słowy, cała machina technologii zda się na nic, jeśli nie wystąpi ktoś, kto umie mówić i dzięki forensycznej wrażliwości doprowadzi do aktu publicznej prawdomówności, w imię praw do życia ${ }^{19}$.

Forensics nie jest więc wariacją na temat relacji nauk ścisłych i obiektu ${ }^{20}$. Słowo forensis w łacinie oznaczało odnoszenie się do forum ${ }^{21}$, przestrzeni wspólnego wytwarzania znaczeń, a dalej określało zdolność budowania argumentu w debacie politycznej lub prawnej. Akcent, jaki kładzie grupa z Goldsmiths na wytwarzanie forum, czynne wkraczanie w jego przestrzeń, bycie na nim widzianym (wystawy), słyszanym (wypowiedź) i użytecznym (dostarczanie dowodów) oraz nakierowanie na samo jądro humanistyki (prawa człowieka), wydaje mi się funkcjonalnym wzorem do zastosowania.

Powrót do idei forum wydaje mi się fundamentalny: zadaniem humanistyki byłoby czynne wytwarzanie wspólnej przestrzeni (retor skupiał uwagę, performatywnie wytwarzat wokół siebie zgromadzenie), w której ustalamy podstawowe normy naszej egzystencji. Forum w tym sensie jest pojęciem nadrzędnym dla pojęcia rynek - oba słowa opisują pozornie tę samą przestrzeń wyprowadzoną z fizyczności greckiej agory. Pierwsze jednak obejmuje

19 Por. wywiad z S. Schuppli Architektura publicznej prawdomówności, http://www.beczmiana. pl/212,architektura_publicznej_prawdomownosci.html (15.11.2015).

E. Weizman Forensic Architecture: Notes from Fields and Forums, dOCUMENTA (13), 100 Note: No 062 , s. 6.

21 E. Weizman Introduction: Forensis, w: Forensis. The Architecture of Public Truth, ed. by Forensic Architecture, Sternberg Press and Forensic Architecture, Berlin 2014, s. 9. 
rozlicznie ludzkie relacje i jest pojęciem szerszym; drugie - tylko relacje wymiany handlowej. Humanistyka musi wydobyć się z przypisania do rynku (na którym nie ma zbyt wielu okazji do oferowania czegoś, za co można zapłacić) i wrócić na forum, zmuszając jednocześnie do przemodelowania idei wspólnej przestrzeni, w której mamy definiować swoje relacje (żyjemy wokół forum, nie wokół rynku).

W praktyce grupy Forensis interesujące wydaje mi się również skuteczne wiązanie nauk ścisłych i społecznych, technologii i prawa, tak by nadrzędną pozycję przyznać humanistyce, co jest ważną odmianą w momencie, gdy już przyzwyczailiśmy się do podrzędnych funkcji przyznawanych humanistom. Wszystko to razem może świadczyć o tym, że można z sukcesem realizować strategie uaktywnienia humanistyki. Warunkiem byłby powrót tam, skąd się wywodzi - do centralnego punktu umożliwiającego samo wytwarzanie tego, co publiczne. Sednem sukcesu grupy Forensic Architecture nie jest jednak gest wspólnotowy, partycypacyjny, relacyjny czy publiczny - badacze, o których wspominam, zaproponowali coś więcej, coś bardziej odważnego, co było nowym, a faktycznie staro-nowym elementem. Chodzi mi oczywiście o autentyczne, także fizyczne i osobiste, publicznie ujawnione aktywne zaangażowanie na rzecz konkretnej, źródłowej idei, idei wywodzonej z pierwotnej tradycji humanistyki: podstawowego prawa (ludzi i nie-ludzi) do przeżycia. 


\section{Abstract}

\section{Roma Sendyka}

JAGIELLONIAN UNIVERSITY (CRACOW)

In the Name of the Dead: Forensic Sensitivity and Public Truthfulness in the Humanities

Is it possible to bring the humanities into the public sphere in a critical way but without engaging in the practices of the public, participative and relational humanities? Looking for examples of such an advanced practice (which would effectively involve the community, being socially useful and at the same time socially critical), we might turn to projects in the fields that emerged with the forensic turn, where the humanities integrate artistic practices, involve new technologies, and critically combine material, hermeneutical and theoretical analysis. Sendyka also strongly emphasizes returning to the sources of the discipline. She demands that the humanities embrace a social orientation: a primary gesture is the reference to the concept of the ancient forum as a space of debate and open and collective thinking.

\section{Keywords}

forensic turn, forum, New Humanities, material witness, forensic architecture, prosopopoeia, situated knowledge, fragile life 